\title{
Balance of interests of stakeholders in the provision of insurance services
}

\author{
Maya Loskutova ${ }^{1, *}$, Tatiana Khnykina $^{2}$ \\ ${ }^{1}$ Financial University under the Government of the Russian Federation (Moscow) St. Petersburg \\ branch, Syezhinskaya Str., 15-17, 197198, St. Petersburg, Russian Federation \\ ${ }^{2}$ Peter the Great St. Petersburg Polytechnic University, Polytechnicheskaya, 29, 195251, St. \\ Petersburg, Russian Federation
}

\begin{abstract}
The owners and heads of companies often make serious financial decisions, both operational and strategic, guided not by traditional criteria for optimality of profitability and risk, but by the desire to satisfy, to one degree or another, the expectations and interests of various interested groups of people both in the company and for its limits. The financial goal of a large corporate structure, in particular an insurance organization, should be formulated on the basis of a balance of interests of all interested parties (stakeholders) of its business in accordance with stakeholder theory. The authors determine the purpose and objectives of this study as the discussion of the nature of the stakeholder approach to the balanced development of economic entities, as well as the insufficient development of methodological approaches to meeting the requirements of stakeholders. The stakeholder's approach allows us to disclose all key aspects of the functioning of an economic entity, and it could be proved that the corporate governance system of insurance organizations should include a mechanism for identifying and predicting the interests of key stakeholders and building on their basis strategic guidelines for coordinating and satisfying the interests of stakeholders.
\end{abstract}

\section{Introduction}

Owners and managers of companies often make serious financial decisions of both operational and strategic nature, guided not by the traditional criteria of optimality in terms of profitability and risks, but by the desire to meet to some extent the expectations and interests of various interested groups of persons both within the company and outside it.

The financial goal of a large corporate structure, in particular an insurance company, should be formulated on the basis of a balance of interests of all interested parties (stakeholders) of its business. This idea is based on the popular stakeholder theory. Stakeholders are individuals or companies that have any interests that meet their needs and expectations, for example, shareholders, employees, managers, contractors, the state and other persons interested in the activities of the company and her actions.

\footnotetext{
Corresponding author: sbe@list.ru
} 
The changes of the modern economy regard various methodological aspects from the perspective of the theory of corporate governance, human resource management and sharing-economy as it was described by Kalinina O. V. [1-3] with a special issued being investigated by Perlovsky L. [4]. When developing a corporate strategy, the search for a balance of interests of stakeholders conflicts with the target criterion for maximizing the value of the business for shareholders (wealth maximization theory), in particular the market value of shares ("market capitalization").

Joint-stock forms of financing business development in Russia will gain momentum in the coming decades. The crisis of 2014-2016 increased the attention of the stock market to the quality of investment analysis and assessment of investment risk when investing in a particular Issuer. Many consulting firms claim that the Issuer can implement the plans in full and within the specified time only if its plans have a balance of interests of stakeholders. Thus, a compromise is needed between maximizing the value of the business for shareholders and finding a balance between the interests of stakeholders.

\section{Materials and methods}

The debatable nature of the stakeholder approach to the balanced development of economic entities, as well as the insufficient development of methodological approaches to meeting the requirements of stakeholders, determined the purpose and objectives of this study.

To reduce the risks of investors in the stock market, rating agencies began to pay close attention to the internal corporate relations of issuers, especially those that are growing and attracting equity capital. For example, Standard\&Poor's (S\&P) is actively promoting its corporate governance rating. Kozlova N. P. believes that the RCU is S\&P's opinion about the extent to which the company applies generally recognized best corporate governance principles designed to serve the interests of financially interested persons, primarily shareholders [5].

Makarov E. I. believes that corporate governance ratings are currently the only practical analysis tool that compares the company's strategy and the relations of some of its stakeholders [6].

Zhukova T. N. considers the features of the stakeholder approach to managing a modern organization in various sectors of the economy [7].

Krasilnikova E. O. reveals the role of stakeholders in the company's activities and considers approaches to interaction with them in domestic and foreign practice [8].

Gresko A. A. consider the need to balance the interests of various stakeholders in the formation of the company's strategy and ensure the effectiveness of its financial and economic activity [9].

Likhtarova O. V. identifies the main categories of stakeholders of the organization and considers their key interests, raising the problem of balancing the interests of various stakeholders in the framework of improving the efficiency of corporate governance of the organization [10].

Nikiforova I. V. Considers the stakeholder approach as the key direction of corporate governance development and the most important tool for ensuring sustainable development of the enterprise [11].

Tkachenko E. N. also believes that a modern organization needs to form interaction with stakeholders from the perspective of satisfying their requirements and maintaining a balance of requirements of various stakeholders in the framework of the implementation of the provisions of the concept of corporate social responsibility [12].

Plakhin A. Ye. Considers a mathematical apparatus with which it is possible to assess the impact on the financial results and financial stability of a company of such aspects as 
the quality of corporate governance, the level of development of corporate social responsibility [13].

Blair J. D. considers the importance of corporate governance for an enterprise in the context of achieving sustainable enterprise development [14].

Brest P. interprets the sustainable development of the enterprise as a way to achieve stability in such aspects as financial activity, social development of the company, fulfillment of obligations to society [15].

Friedman A. L. and S. Miles are considering the possibility of achieving high financial results by satisfying the interests of various stakeholder groups [16].

Frooman J. pays particular attention to the transformation of interests of stakeholders at different stages of the enterprise life cycle, indicating that the development of the enterprise leads to an increase in the number of stakeholders and the expansion of the spectrum of their interests [17].

Linh Do. H. believes that the implementation by the enterprise of the provisions of the concept of corporate social responsibility leads to the satisfaction of the interests of various groups of stakeholders [18]. Corporate social responsibility is a voluntary concept adopted by an enterprise to maintain a balance of social interests of participants in a corporate structure, aimed at regularly improving the quality of life of the external and internal environment, employees and their families. As part of the implementation of corporate social responsibility by business entities, the requirements of the organization's stakeholders are met.

The balanced development of an economic entity on the basis of meeting the requirements of interested parties is an optimal ratio of financial and non-financial indicators based on the optimal combination of external and internal development factors in the absence of reasonable and economically significant claims from stakeholders. Accordingly, the basis for sustainable development should be the financial stability of the economic activity of an economic entity, which is influenced by the socio-economic interests of stakeholders. Thus, sustainability of development implies rational training and fulfillment of the requirements of stakeholders in objective conditions. It should be emphasized that the lack of balance will also be the excessive satisfaction of the requirements of certain stakeholders, which caused negative phenomena both in the internal and external environment of the organization. The need for management to prioritize stakeholders and their most significant requirements is determined by economic feasibility: an economic entity cannot satisfy a complete list of stakeholder requirements and at the same time maintain financial stability and development resources. According to the theory and practice of economics, when implementing a stakeholder approach to the sustainable development of economic entities, the key aspect of stakeholder analysis is economic benefit.

An insufficient analysis of the interests of key stakeholders of the company has the potential to cause economically irreparable damage to the development of an economic entity. Accordingly, the balance and mutual coordination between the interests of stakeholders and the development of an economic entity, on the contrary, can contribute to the growth of a company's competitiveness due to its good reputation in the market, high attractiveness for investors, and a favorable internal psychological climate. Consequently, the leadership of the economic entity within the framework of the stakeholder approach is not enough just to satisfy the requirements of stakeholders in a timely manner, it is necessary to maintain a balance of various components in relations with stakeholders.

For a more comprehensive consideration of the features of the implementation of the stakeholder approach to the sustainable development of economic entities, it is necessary to clarify the concept of "balance" as applied to stakeholders. Analysis of the economic literature showed that the category of "balance", widely used in the framework of the 
stakeholder approach, has different formulations regarding the economic nature and characteristics of the problem under consideration. According to S.A. Novoselova, considering this concept from the perspective of management accounting, balance is the degree of discrepancy between the planned and current development of the economic entity. Accordingly, the balanced development of the organization on the basis of meeting the requirements of stakeholders can be considered on the basis of the analysis of a certain set of factors affecting the achievement of planned development indicators.

In the works of the largest strategic management theorist I. Ansoff, the following approach to the definition of the concept of balance in the development of an economic entity is presented. According to I. Ansoff, balance is an optimal combination of strategic business components for the current conditions of development, ensuring minimum costs for the economic entity, including loss of time [6]. D. Norton and R. Kaplan consider the balanced development of the company in the form of a system of correlation of financial and non-financial indicators of the economic entity, paying special attention to the balance between external and internal factors of development, which is also consistent with the development concept based on the interests of stakeholders.

An important element in the implementation of the stakeholder approach to the sustainable development of economic entities is the assessment of the requirements of stakeholders themselves. It should be emphasized the dialectical nature of the requirements of stakeholders and the possibilities of their implementation by the economic entity. So, the requirements of interested parties themselves form favorable conditions for them and a format for interaction with an economic entity, but can only be realized if the company in question accepts these conditions.

The strategic requirements of stakeholders are an expression of the basic aspects of the functioning of an economic entity, and are also based on long-term interests and targets, including integrated ones that determine the success of economic activity.

The tactical requirements of stakeholders are basically interested in choosing methods by an economic entity regarding solving problems arising in the course of economic activity. These requirements, upon further consideration, can also be divided into functional and non-functional.

Accordingly, the functional requirements of the interested parties are limited by the range of opportunities for the economic entity to act within the framework of wellfunctioning business functions and suggest the existence of implementation mechanisms in a predictable environment.

Non-functional requirements of stakeholders, in turn, are, on the contrary, an extension of the range of possible options for actions by company management in atypical environmental conditions.

The transformational requirements of stakeholders represent the socio-economic opportunities and disequilibrium states of business activity that an economic entity must possess in order to transition to a state that is beneficial for interested parties [19-24].

Within the framework of the research problem, the proposed methodology for ensuring the requirements of interested parties is divided into two successive stages, discussed below.

Stage one: stakeholder analysis. This stage includes analytical procedures and regular monitoring of changes in the list of stakeholders that are significant for the company and their main interests. On the practical side of the issue, the complexity of this stage of the methodology implementation lies in the large amount of analytical work, the need to search and systematize information using various techniques of economic analysis and business environment assessment.

A company can identify stakeholders by analyzing the environment, using criteria of importance, significance, support / opposition. In addition, there is a well-known Mitchell 
model for determining the importance of stakeholders - having the power, legitimacy and urgency of the requirements for the company. In Russian practice, it is customary to distinguish the following groups of stakeholders: shareholders (owners), employees, buyers, partners, government bodies and local communities.

When identifying company stakeholders, it is recommended to take into account the following characteristics of the relationship (Figure 1):

\begin{tabular}{|c|c|}
\hline Responsibility & $\begin{array}{l}\text { - relationships recorded in } \\
\text { financial and legal documents, } \\
\text { contracts, corporate codes }\end{array}$ \\
\hline Influence & - formal and informal \\
\hline Proximity & $\begin{array}{l}\text { - internal and external } \\
\text { stakeholders }\end{array}$ \\
\hline Dependence & $\begin{array}{l}\text { - stakeholder dependence on the } \\
\text { organization and the results of } \\
\text { its activities (employees, } \\
\text { customers) }\end{array}$ \\
\hline Representativeness & $\begin{array}{l}\text { - stakeholders representing } \\
\text { anyone's interests (society, } \\
\text { state, environment) }\end{array}$ \\
\hline
\end{tabular}

Fig. 1. Characteristics of relationships with stakeholders.

The second stage: analysis of the requirements of stakeholders and the possibilities of satisfying them. This stage is aimed at finding opportunities for a balanced satisfaction of stakeholder requirements, which implies a parallel assessment of the financial resources available to the economic entity to solve the identified problems. The contents of the second stage are the following tasks (Figure 2).
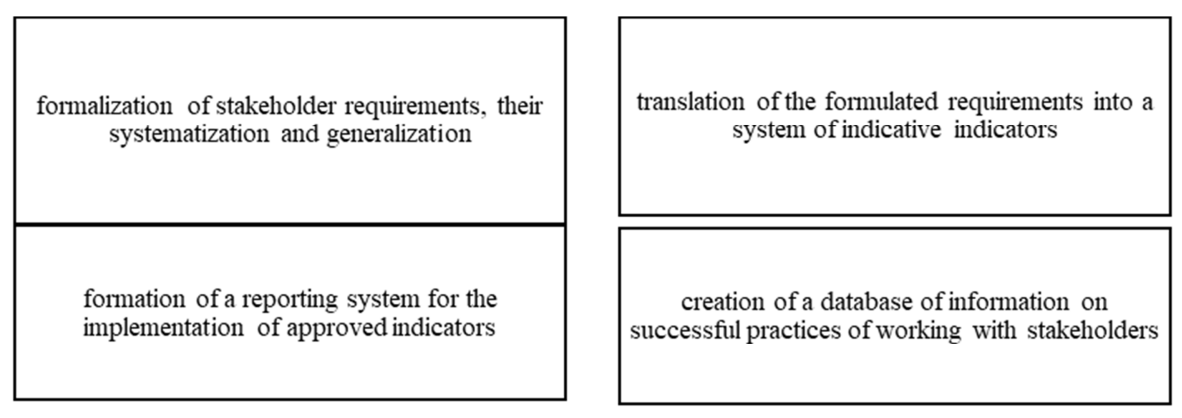

Fig. 2. Tasks of the second stage.

The central objective of the second stage of the methodology for ensuring the requirements of interested parties is the formation of a balanced structure of financial flows for the optimal distribution of financial resources available to the company in order to coordinate them with the requirements of stakeholders. 


\section{Results of the research}

The weak point of the modern model of domestic corporate governance in Russia is the excess of the importance of the rights of shareholders over the rights of employees, managers, suppliers, consumers and other interested parties. Remaining without proper attention from corporate governance, these groups of people do not receive satisfaction of their needs, which ultimately creates conditions that do not favorably affect the activities of the enterprise. For this reason, corporate governance should not address the issue of how much relationship with the owners of the company, how much relationship with other stakeholders, which play an equally important role in the formation of the final results of the organization (Figure 3).

\begin{tabular}{|c|c|}
\hline The proprietors & - rate of return on capital and financial stability \\
\hline Management & $\begin{array}{l}\text { - the value of key performance indicators established } \\
\text { for each level of management }\end{array}$ \\
\hline State & $\begin{array}{l}\text { - timeliness and completeness of tax payments, } \\
\text { compliance with regulatory requirements for the } \\
\text { functioning of insurance }\end{array}$ \\
\hline Staff & $\begin{array}{l}\text { - providing guarantees established by the labor code, } \\
\text { corporate social package }\end{array}$ \\
\hline Counterparties & - timeliness and completeness of payables \\
\hline Consumers & $\begin{array}{l}\text { - wide range of insurance products, timeliness and } \\
\text { completeness of insurance payments, long-term } \\
\text { functioning of the company }\end{array}$ \\
\hline Local communities & $\begin{array}{l}\text {-participation in environmental and social } \\
\text { development programs of the territory }\end{array}$ \\
\hline
\end{tabular}

Fig. 3. Stakeholders of the insurance organization and their expectations.

The key stakeholders of the insurance organization and their requirements to certain expected actions and results. In general, two styles of corporate governance can be distinguished in relation to all stakeholders: passive management and active management.

With passive management, one can observe a kind of "emptiness" where the enterprise exists, its corporate governance and stakeholders who hope that the company's managers will take into account their interests. With active management, everything is different. In this case, the enterprise and corporate governance is aimed at new actions and measures in order to satisfy the interests of all stakeholders through various practical tools. Depending on whether the interests of all stakeholders are satisfied or not, the management of the enterprise can get both an effective business model and unprofitable if their corporate governance does not take into account the interests of other interested parties (except for shareholders and investors of the company).

It is advisable to consider the level of development of components of corporate social responsibility as an indicator of taking into account the interests of stakeholders. The company's activity in the implementation of certain CSR components receives one or another feedback from stakeholders on the company's activities. Accordingly, if this response is positive, useful for the company, it means that the specific component of CSR has a positive effect on the company's activities.

Thus, it is possible to compare the level of development of CSR components and the degree of usefulness of the response back to the company. 
We propose to calculate the CSR impact index on company performance using the following formula (1):

$$
\mathrm{I}_{\mathrm{CSR}}=\frac{\sum_{1}^{n} \frac{Y i}{X i}}{n}
$$

Where $Y_{i}$ is the level of feedback; $X_{i}$ is the level of development of the CSR component; $N$ is the number of investigated components of CSR.

We have formed the calculation Table 1, which presents a list of CSR components and a range of performance estimates.

Table 1. Calculation algorithm of the index of the impact of CSR on company performance.

\begin{tabular}{|c|c|c|c|c|c|c|c|}
\hline \multirow[b]{2}{*}{ CSR components } & \multicolumn{3}{|c|}{$\begin{array}{l}\mathrm{X}_{i} \text { - level of development of CSR } \\
\text { components }\end{array}$} & \multicolumn{3}{|c|}{$Y_{i}$ - backward response level } & \multirow[b]{2}{*}{$\mathrm{Y}_{i} / \mathrm{X}_{i}$} \\
\hline & $\begin{array}{c}\text { Below } \\
\text { average: } 0 \\
\text { to } 0.35\end{array}$ & $\begin{array}{c}\text { Medium: } \\
0.35 \text { to } \\
0.65\end{array}$ & $\begin{array}{c}\text { Above } \\
\text { average: } \\
0.65 \text { to } 1\end{array}$ & $\begin{array}{l}\text { Below } \\
\text { average: } 0 \\
\text { to } 0.35\end{array}$ & $\begin{array}{l}\text { Medium: } \\
0.35 \text { to } 0.65\end{array}$ & $\begin{array}{c}\text { Above } \\
\text { average: } \\
0.65 \text { to } 1\end{array}$ & \\
\hline $\begin{array}{l}\text { Customer } \\
\text { interaction }\end{array}$ & \multicolumn{3}{|c|}{ The quality of goods and services } & \multicolumn{3}{|c|}{ Brand loyalty } & \\
\hline $\begin{array}{l}\text { Partner } \\
\text { Engagement }\end{array}$ & \multicolumn{3}{|c|}{ Company business practices } & \multicolumn{3}{|c|}{$\begin{array}{l}\text { Loyalty of partners to the } \\
\text { company }\end{array}$} & \\
\hline $\begin{array}{l}\text { Interaction with } \\
\text { competitors }\end{array}$ & \multicolumn{3}{|c|}{ Fair Competition } & \multicolumn{3}{|c|}{ Fair Competition } & \\
\hline HR interactions & \multicolumn{3}{|c|}{ Personnel and Social Policy } & \multicolumn{3}{|c|}{ Employer Loyalty } & \\
\hline $\begin{array}{l}\text { Media } \\
\text { engagement }\end{array}$ & \multicolumn{3}{|c|}{ Reputation Management } & \multicolumn{3}{|c|}{ Company image } & \\
\hline $\begin{array}{l}\text { Society (media } \\
\text { aspect) }\end{array}$ & \multicolumn{3}{|c|}{ Impact on Public Opinion } & \multicolumn{3}{|c|}{ Company Approval } & \\
\hline $\begin{array}{l}\text { Society } \\
\text { (philanthropic } \\
\text { aspect) }\end{array}$ & \multicolumn{3}{|c|}{$\begin{array}{l}\text { Implementation of global social } \\
\text { projects }\end{array}$} & \multicolumn{3}{|c|}{ Company Approval } & \\
\hline
\end{tabular}

We will calculate the index of CSR impact on the effectiveness of the insurance company PJSC Rosgosstrakh (table 2).

Table 2. Calculation of the index of the impact of CSR on the effectiveness of PJSC "Rosgosstrakh".

\begin{tabular}{|l|c|c|c|c|}
\hline CSR components & $\begin{array}{c}\mathrm{X}_{i} \text { - level of } \\
\text { development of } \\
\text { CSR components }\end{array}$ & $\begin{array}{c}\mathrm{Y}_{i} \text { - backward } \\
\text { response level }\end{array}$ & $\mathrm{Y}_{i} / \mathrm{X}_{i}$ & \multirow{2}{*}{$\mathrm{I}_{\text {ксо }}$} \\
\hline Customer interaction & 0,75 & 0,7 & 0,933333333 & \\
\hline Partner Engagement & 0,7 & 0,65 & 0,92857143 & \\
\hline Interaction with competitors & 0,65 & 0,6 & 0,92307692 & \multirow{2}{*}{1,052} \\
\hline HR interactions & 0,7 & 0,74 & 1,05714286 & \\
\hline Media engagement & 0,56 & 0,62 & 1,10714286 & \\
\hline Society (media aspect) & 0,43 & 0,56 & 1,30232558 & \\
\hline Society (philanthropic aspect) & 0,45 & 0,5 & 1,11111111 & \\
\hline
\end{tabular}


Figure 4 illustrates the relationship between the development of CSR components in PJSC Rosgosstrakh and the feedback from the company's stakeholders.

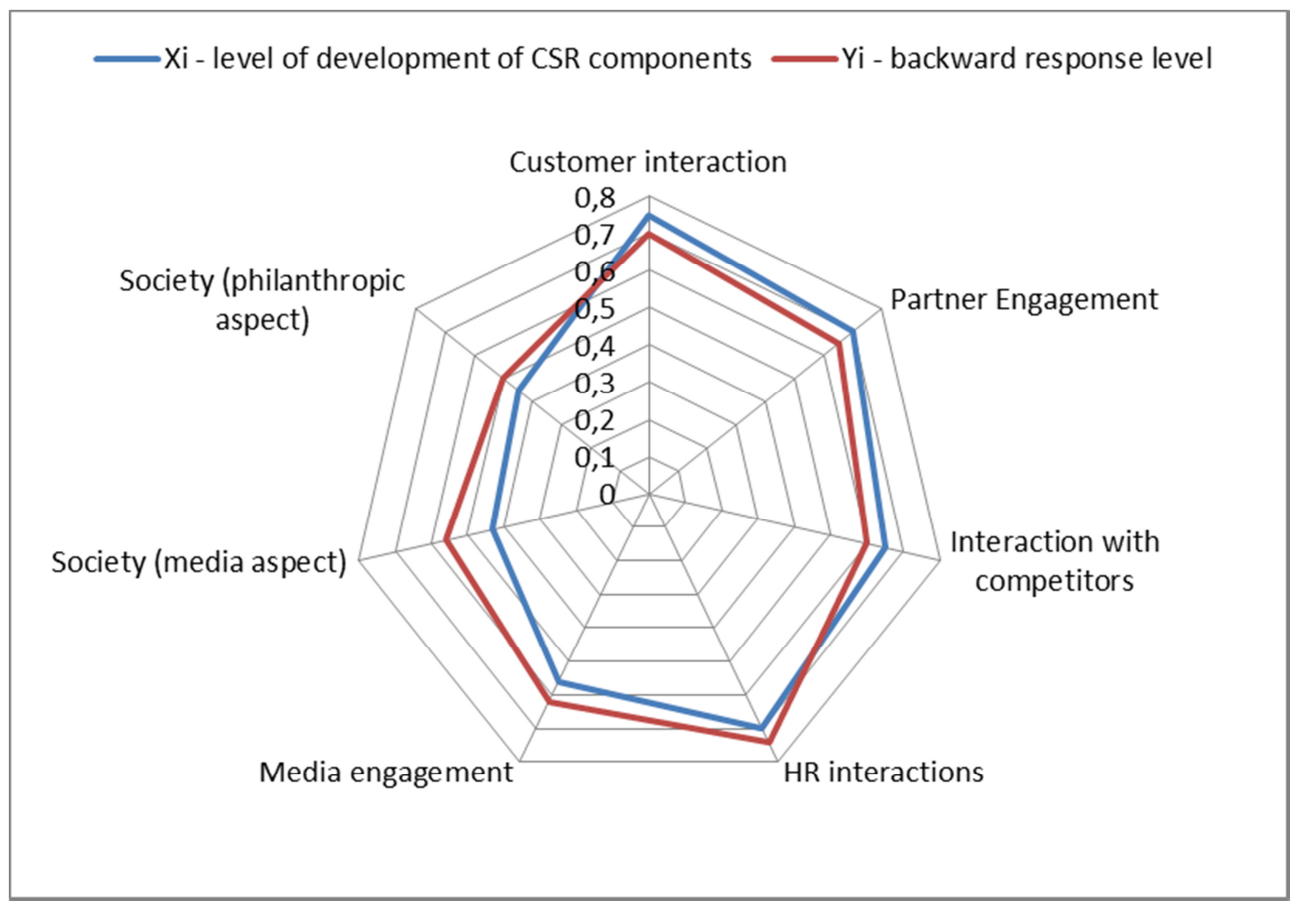

Fig. 4. Correlation between the development of CSR components in Rosgosstrakh PJSC and the feedback of the company's stakeholders.

Thus, the feedback from stakeholders is often proportional to the level of development of the company's corporate social responsibility components.

\section{Discussion}

From the point of view of the company, the mechanism of managing relations between the company and stakeholders is an important organizational process that allows you to plan the company's activities together with stakeholders to achieve the goals and objectives facing the company and to address significant issues of stakeholders themselves. The main problems in domestic business that impede the development of the process of its interaction with stakeholders can be considered the lack of legislatively established rules of conduct between all interested parties and the attitude of companies to stakeholders in general. In order to organize effective interaction both for the company and for all interested stakeholders, a mechanism of interaction with strategies, interaction tools and other integral elements is needed, thanks to which the level of social responsibility of the company will become close to the level of development of social partnership in Western companies [9].

\section{Conclusion}

Thus, the stakeholder approach allows us to disclose all key aspects of the functioning of an economic entity. Taking into account the requirements of interested parties, long-term 
development plans and projects are developed, and the co-ordination of the company's production, financial and investment activities is ensured.

The corporate governance system should include a mechanism for identifying and predicting the interests of key stakeholders and building on their basis strategic guidelines for coordinating and satisfying the interests of stakeholders. To accomplish this task, it is necessary to form a number of internal corporate institutions:

1) institutions for the coordination of interests of stakeholders;

2) a system of standards for relations with stakeholders (shareholders, employees, consumers, partners, etc.);

3) formal and informal mechanisms for resolving contradictions.

A number of tools have been identified that can be divided into 4 areas: monitoring and planning, information, involvement and cooperation. Among the main tools of the first group, various types of questionnaires, surveys, monitoring and analysis of information are distinguished in order to better understand the interests and requirements of stakeholders with further planning for possible interaction with them.

Informing implies one-way contact of the company with stakeholders, when the company itself publishes information about its activities and opportunities for cooperation, organizes public events and presentations, and openly advertises its activities. The organization of bilateral contact indicates the involvement of stakeholders in the company through open dialogues, various votes, and expert groups. But the most effective tools can be considered directly methods of cooperation: business negotiations, conclusion of contracts, joint projects, agreements.

\section{References:}

1. O. Rasskazova, O. Kalinina, E. Zotova. MATEC Web of Conf. 170, 01058 (2018).

2. O. Kalinina, L. Alekseeva, D. Varlamova, S. Barykin, I. Kapustina. E3S Web of Conferences 110, 02103 (2019).

3. V. Vilken, O. Kalinina, S. Barykin, E. Zotova. IOP Conference Series: Materials Science and Engineering (2019) DOI: 10.1088/1757-899X/497/1/012037

4. S. Vorobyov, L. Perlovsky, V. Yadykin. IOP Conference Series: Materials Science and Engineering 497, 012038 (2019).

5. N. P. Kozlova. Economy. Business. Banks 3 (24), 58-68 (2018).

6. E. I. Makarov, G. N. Franovskaya, E. A. Shubina, Bulletin of Voronezh State University. Series: Economics and Management1, 36-42 (2018).

7. T. N. Zhukova, Bulletin of the Faculty of Management 1-1, 272-276 (2017).

8. E. O. Krasilnikova. Business education in the knowledge economy 2, $50-54$ (2019).

9. A. A. Gresko, K. S. Solodukhin. Azimuth of Scientific Research: Economics and Management 6(3), 115-118 (2017).

10. O. V. Likhtarova, Balkan Scientific Review 2(4), 102-105 (2019).

11. E. V. Nikiforova. Azimuth of Scientific Research: Economics and Management 3(24), 213-216 (2018).

12. I. N. Tkachenko. Management sciences in the modern world 1(1), 205-209 (2018).

13. A. E. Plakhin, Vestnik NGII 10(89), 97-108 (2018).

14. J. D. Blair, M. D. Fottler, Journal for Healthcare Quality 13(3), 38-39 (1991). DOI:10.1097/01445442-199105000-00019 
15. P. Brest, R. J. Gilson, M. A., Wolfson How Investors Can (and Can't) Create Social Value (SSRN Electronic Journal, 2018). DOI:10.2139/ssrn.3146718

16. A. L. Friedman and S. Miles, Journal of Management Studies 39(1), 1-21 (2002). DOI:10.1111/1467-6486.00280

17. J. Frooman. Business \& Society 44(1), 3-31 (2005). DOI: $10.1177 / 0007650304273434$

18. D. Linh, T. V. Anh. Economic Annals-XXI 165(5-6), 143-151 (2017). DOI: 10.21003/ea.V165-29

19. E. Guillamon-Saorin, M. Kapelko, S. Stefanou, Sustainability 10(7), 2277 (2018). DOI:10.3390/su10072277.

20. John D. Blair, Starr A. Blair, Myron D. Fottler, Timothy W. Nix, G. Tyge Payne, Grant T. Savage, Advances in Health Care Management 3, 319-346 (2002). DOI: $10.1016 / \mathrm{S} 1474-8231(02) 03014-8$

21. A. Fletcher, J. Guthrie, P. Steane, G. Roos, S. Pike. Journal of Intellectual Capital 4(4), 505-527 (2003). DOI:10.1108/14691930310504536

22. A. I. Krivtsov. Growth Poles of the Global Economy: Emergence, Changes and Future Perspectives (2020). DOI: 10.1007/978-3-030-15160-7_34.

23. F. Zhang, L. Zhu. Business Strategy and the Environment (2019). DOI:10.1002/bse. 2298

24. M. H. Zaharia, F. A. Hodorogea Expert Systems with Applications 72 (2016). DOI:10.1016/j.eswa.2016.12.006. 